\title{
Discovering the entrepreneurial endowment of the youth
}

\author{
Alex Bignotti and Ingrid le Roux \\ Department of Business Management, University of Pretoria, Pretoria, South Africa
}

\begin{abstract}
Purpose - Entrepreneurship is considered as a possible solution to youth unemployment, and the number of initiatives fostering youth entrepreneurship has multiplied accordingly, also in Africa. However, the effectiveness of such initiatives also lies in whether young people display personality and contextual dimensions conducive to starting and running businesses. This paper examines the composition of young South Africans' "entrepreneurial endowment", represented by personality traits and contextual variables commonly associated with entrepreneurship.
\end{abstract}

Design/methodology/approach - This paper surveyed secondary students using a questionnaire constructed from validated measurement instruments, obtaining 827 valid responses. It employed exploratory factor analysis to investigate the composition of respondents' entrepreneurial endowment. It also compared respondents' entrepreneurial endowment across demographic variables by means of t-tests and ANOVA.

Findings - The results reveal the existence of an entrepreneurial endowment composed of: need for achievement, locus of control, community support, two role-models subconstructs and two family-support sub-constructs. Significant differences from the perspective of gender, cultural background and entrepreneurship education also emerged. Practical implications - The findings confirm that young South Africans have the entrepreneurial endowment needed to be the recipients of entrepreneurship support and highlight relevant differences across demographic variables.

Originality/value - From a theoretical perspective, this paper unveils the structure of young South Africans' entrepreneurial endowment, composed of four unique dimensions not found in previous research. The insights gained from comparing entrepreneurialendowment results across different groups offer practical implications.

Keywords Entrepreneurial endowment, Personality traits, Contextual variables, Gender, Culture, Entrepreneurship education, Secondary students, South Africa, Youth entrepreneurship

Paper type Research paper 


\section{Introduction}

Unemployment has plagued young people on a worldwide scale in recent years, both in developed and emerging economies. Unemployed youth were 73.3 million in 2014, and the global youth unemployment rate, which settled at 13 per cent for the 2012-2014 period, is almost three times as high as the adult unemployment rate (ILO, 2015). As countries depend on their youth to build their future, it is imperative that young people have safe prospects ahead of them. Failure to enable young people to find employment can have negative economic and social repercussions on the wellbeing of nations (Bell and Blanchflower, 2011). At the backdrop of this scenario, entrepreneurship has been widely regarded as a possible solution to the inability of the labour force to accommodate young people completing their formal education every year (Fatoki and Chindoga, 2012). It is increasingly the auspice of national political leaders that young people become selfemployed by starting and running businesses. Efforts to encourage young people to choose entrepreneurship as a career have steadily increased over time, on the part of both governments and institutions providing entrepreneurship training and funding support (Singer et al., 2015).

In South Africa, a number of agencies have been set up in order to help individuals, including young people, to start businesses: the Small Enterprise Development Agency, the Small Enterprise Finance Agency, the National Youth Development Agency, the Technology and Innovation Agency, and the National Empowerment Fund (Herrington et al., 2015), to name a few. However, the effectiveness of these agencies and funds, which have periodically been restructured, remains doubtful. At the same time, the link between practice and research is weak. It is uncertain whether the initiatives put in place to foster youth entrepreneurship take into account the research findings on the effectiveness of such interventions. A dilemma to be solved is whether interventions aimed at encouraging youth entrepreneurship target the people that have what it takes to start businesses. Research has proved that there is more to the business start-up decision than just training and funding.

It is therefore important to investigate the different angles from which to understand who the entrepreneur is, as well as the intricate phenomenon of entrepreneurship. One such angle is personality based and underlies the emergence and development of the Trait School. Authors belonging to this school have investigated the personality traits of entrepreneurs. The investigation of personality traits has been subject to criticism since personality traits have not proven to explain entrepreneurial behaviour exhaustively 
(Llewellyn and Wilson, 2003). However, there has been a re-emergence of research on entrepreneurial personality traits, based on the claim that, even though they are not the only variables explaining the entrepreneurship phenomenon, they contribute to the understanding of the business start-up decision (Liñán and Fayolle, 2015). Trait-based research has consistently found that some personality traits are associated with entrepreneurship, such as need for achievement, locus of control, propensity to risk, tolerance of ambiguity, self-confidence, and capacity to innovate (Marques et al., 2012). Referring to the above-stated dilemma, it can be argued that interventions seeking to foster youth entrepreneurship should target young people that exhibit the personality traits that have emerged from years of entrepreneurship research.

There is also evidence that contextual variables, such as role models, family support and community support, are associated with the business start-up decision, as posited by the contextual view of entrepreneurship (Wiklund et al., 2011). This perspective advances that entrepreneurial behaviour is influenced by the context in which people operate, such as their household, family, and other social networks (Welter, 2011). Few studies (Altinay et al., 2012; De Pillis and Reardon, 2007; Korunka et al., 2003; Obschonka et al., 2012) have complemented the observation of the personality traits of entrepreneurs with the investigation of which contextual variables play a role in the business start-up decision. However, there is evidence that even one's personality is shaped by the environment (Hofstede and McCrae, 2004).

To sum up, it appears that people with personality traits and contextual variables associated with entrepreneurship are more likely to start businesses. In this paper, the ensemble of personality traits and contextual variables associated with entrepreneurship is termed "entrepreneurial endowment", connoting a set of variables developed over time or found stably in one's surroundings, and thus representing certain personal and contextual characteristics. Hence, the research question underlying this paper is: Do young people in South Africa exhibit an entrepreneurial endowment? Seeking an answer to this research question will facilitate the understanding of whether young South Africans have what it takes to start businesses in terms of their personality and context. Consequently, it will also provide an insight into the potential of entrepreneurship-oriented initiatives to foster youth entrepreneurship in South Africa.

Given that personality traits are fairly stable over time (Caliendo et al., 2014), the investigation of personality traits among the youth may begin with adolescence. Typically, entrepreneurship research using secondary students as the research population is scarce. 
Secondary students represent a relevant target population because there is evidence that career interests are already formed during adolescence (Fatoki and Chindoga, 2012). In other words, when looking at the personality traits that make up the entrepreneurial endowment, it can be argued that such personality traits should have been developed by secondary-school age (Meeus et al., 2011). The same line of thought applies to entrepreneurial contextual variables such as role models, family support, and community support, which are part of one's environment and can thus be experienced already during adolescence.

This paper measures the entrepreneurial endowment of a sample of students at South African secondary schools, aged 16 to 18 years old. It makes use of a questionnaire constructed from validated measurement instruments and verifies the behaviour of secondary students on the personality traits and contextual variables investigated. This paper also seeks to develop more insights into the entrepreneurial endowment of secondary students by comparing results on a set of demographic variables: gender, native language, and entrepreneurship education. It is crucial for interventions aimed at fostering youth entrepreneurship to target young people that exhibit the entrepreneurial endowment associated with business start-up decisions. This paper's contribution lies in the determination of whether students at South African secondary schools should be the targets of such interventions under an entrepreneurial-endowment lens.

\section{Literature review}

This section is devoted to the literature on the entrepreneurial endowment with a focus on the youth, including a discussion on studies conducted in Sub-Saharan Africa, and to the literature on the variables according to which the entrepreneurial endowment may differ across young individuals.

\section{The entrepreneurial endowment}

This literature review section is aimed at determining which constructs may constitute the entrepreneurial endowment, which will be the focus of this paper's investigation. More specifically, this section focuses on the personality view and the contextual view of entrepreneurship.

Entrepreneurship research under the personality lens spans several decades. Research in this field is divided by Gartner's (1989) seminal article "Who is an 
entrepreneur?' is the wrong question", which was written in the light of failed attempts to distinguish entrepreneurs from non-entrepreneurs successfully in terms of personality traits. Since then, scholars have renewed their efforts to establish what personality traits entrepreneurs have, and recent meta-analytical research (Brandstätter, 2011; Rauch and Frese, 2007; Zhao et al., 2010; Zhao and Seibert, 2006) points to more conclusive results. As Rauch and Frese (2007) argue, the call to abandon the personality view of entrepreneurship was based on the observation of results of narrative literature reviews, whose inability to observe small but important relationships was redressed by recent metaanalytical reviews. Moreover, the use of specific, narrow, personality traits (such as need for achievement, locus of control, and tolerance of ambiguity), as opposed to more generic, broad, clusters of traits, such as The Big Five (openness to experience, conscientiousness, extraversion, agreeableness, and neuroticism), has proven to yield higher validities in entrepreneurship research (Leutner et al., 2014; Rauch and Frese, 2007). This paper follows this same narrow-trait approach in determining the composition of the entrepreneurial endowment.

Examples of narrow personality traits matched with entrepreneurial activity are need for achievement, locus of control and tolerance of ambiguity. Need for achievement is a personal trait that is exhibited by individuals who seek challenging tasks, accept responsibility for them and demand feedback on their execution (McClelland, 1961). In the light of the challenges posed by entrepreneurial activities such as opportunity identification and exploitation, this trait is crucial to the successful fulfilment of such activities. There is empirical evidence that entrepreneurs have higher levels of achievement motivation than non-entrepreneurs (Jayawarna et al., 2013; Stewart and Roth, 2007). Internal locus of control, or more simply "locus of control", is defined as people's attribution of the reasons for an occurrence to themselves (Rotter, 1966). People exhibiting locus of control experience greater levels of ownership of their actions, such as business start-up, and of subsequent results, thus potentially applying more effort when performing entrepreneurial activities. Locus of control has been found to influence entrepreneurial behaviour positively (Caliendo et al., 2014; Hsiao et al., 2016). Tolerance of ambiguity corresponds to people's propensity to view challenging situations favourably where sufficient information is lacking (Koh, 1996). It has been observed that tolerance of ambiguity is associated with entrepreneurial intentions (Espíritu-Olmos and Sastre-Castillo, 2015). Entrepreneurs possess this trait when, in the light of the information gaps faced when exploiting a market opportunity and the associated risk, they do not shrink from this task and are able to take 
action. Before addressing the contextual view of entrepreneurship, and considering the present context of investigation, it is worth ending the discussion on the personality view of entrepreneurship by reviewing studies on the entrepreneurial traits of young people conducted in Sub-Saharan Africa.

The literature on the entrepreneurial traits of young people in Sub-Saharan Africa has followed disparate approaches. One of the earliest attempts to determine the entrepreneurial traits of young people in Sub-Saharan Africa is the study by Van Eeden et al. (2005), which reported on the levels of undergraduate university students' entrepreneurial orientation, defined as "the combination of psychological traits, characteristics, attitudes and values" representing entrepreneurially-inclined individuals. The authors compared students in South Africa, the USA and the Netherlands and found that South African students' entrepreneurial orientation is made up of the following traits: competing against self-imposed standards, dealing with failure, drive and energy levels, and goal setting and perseverance. Farrington, Venter, Schrage, et al. (2012) later replicated the same study and found that the same four entrepreneurial traits characterised South African students, albeit in a different order of relative importance.

In another study, Farrington, Venter and Louw (2012) surveyed undergraduate university students in South Africa and examined which demographic variables are related to their entrepreneurial intentions. Their study revealed that students' entrepreneurial intentions varied with the university they attended, their level of study and their ethnicity. Tessema Gerba (2012) followed an approach more in line with the present study and adopted the Theory of Planned Behaviour in the investigation of young people's entrepreneurial intentions and related factors. In his study, conducted among undergraduate university students in Ethiopia, he found that young people's entrepreneurial intentions are significantly related to their attitudes toward entrepreneurship, subjective norm, self-efficacy, need for achievement, locus of control and instrumental readiness, the latter being a contextual variable encompassing access to capital, access to information and social networks.

The remainder of this literature review section focuses on the contextual view of entrepreneurship in an effort to identify the entrepreneurial endowment dimensions representing contextual variables. The contextual view of entrepreneurship has more recently appeared in research. This view is meant to balance an overreliance on personal factors in understanding the entrepreneurship phenomenon (Wiklund et al., 2011). As Welter (2011) points out, there can be different contextual dimensions impacting the 
emergence of entrepreneurial behaviour. Taking into account this paper's research population, components of the social and institutional contexts as defined by Welter (2011), such as one's networks, household and family, are most relevant. It can be postulated that contextual variables playing a role in fostering youth entrepreneurship are more influential in the immediate context, such as one's family, community and role models.

Family support represents the support people receive from their family for engaging in entrepreneurial behaviour (Chang et al., 2009). For instance, there is evidence that family entrepreneurial background influences the intention to start a business (Altinay et al., 2012) and that family support-which may encompass human, social and financial capital—contributes to entrepreneurial success (Powell and Eddleston, 2013). Community support, often equated with social networks, is the support the community gives to individuals by providing valuable resources such as information, advice and even finance (Tas et al., 2012). There is evidence that entrepreneurial social capital impacts on firm performance positively (Stam et al., 2014) and influences business idea generation in adolescents (Obschonka et al., 2012). Role models have proven to be an influential contextual variable (Karimi et al., 2014), especially by way of "learning by example", and are usually represented by people in one's close circle of acquaintances (Bosma et al., 2012). For instance, Chlosta et al. (2010) and Hoffmann et al. (2014) observed that having parental role models increases the likelihood of being self-employed in future.

In the light of the above discussion, the entrepreneurial endowment investigated in this paper is composed of the following six dimensions: need for achievement, locus of control, tolerance of ambiguity, role models, family support and community support. Other personality traits and contextual variables associated with entrepreneurship exist in the literature. However, in view of this paper's research population of secondary students and the corresponding appropriateness of a concise measurement instrument, the entrepreneurial endowment framework was kept parsimonious.

\section{Gender, culture and entrepreneurship education}

Having defined the entrepreneurial endowment as the ensemble of personality traits and contextual variables commonly associated with entrepreneurship, it must be acknowledged that these dimensions are unlikely to be identical for all individuals. This literature review section addresses variables according to which the entrepreneurial 
endowment may differ across respondents, with a focus on studies surveying young people.

From the literature, it appears that young males and females differ on several entrepreneurial endowment dimensions. Wilson et al. (2007) examined gender differences in self-efficacy and entrepreneurial intentions among middle and high school students in the USA and found that male adolescents have higher levels of both constructs. Karimi et al. (2014) conducted a study among university students in Iran and analysed gender differences in the relationships between constructs of the Theory of Planned Behaviour and between role models and the antecedents of the same theory. Their findings suggest gender differences in the effect of attitudes toward entrepreneurship and subjective norm on entrepreneurial intentions and in the influence of role models on attitudes toward entrepreneurship and perceived behavioural control. In Sub-Saharan Africa, Tessema Gerba (2012) analysed gender differences among university students in Ethiopia and found that male students have higher levels of attitudes toward entrepreneurship, subjective norms, self-efficacy and need for achievement than female students. Female students, on the other hand, exhibited lower levels of instrumental readiness than male students.

Differences in entrepreneurial endowment dimensions among young people also appear across cultures. Mueller and Thomas (2001) investigated differences in the entrepreneurial traits of innovativeness and locus of control among undergraduate university students in fifteen countries. Based on the IBM Study Dimensions of Culture (Hofstede and McCrae, 2004), their study revealed that young people from cultures characterised by high individualism and low uncertainty avoidance are likely to display higher levels of innovativeness and locus of control. In their study on entrepreneurial traits comparing undergraduate university students in three countries, including South Africa, Van Eeden et al. (2005) observed significant differences across countries for most of the entrepreneurial traits investigated. The authors ascribed this variation in entrepreneurial traits to differences in culture. Farrington, Venter and Louw's (2012) study, as already mentioned, revealed significant differences in entrepreneurial intentions between students of different ethnic groups, which could also be attributed to differences in culture associated with ethnic groups.

Finally, it is evident from the literature that individuals in entrepreneurship education are more likely to have or develop entrepreneurial traits. In his study, Tessema Gerba (2012) observed that university students who have completed an entrepreneurship course 
exhibit higher entrepreneurial intentions than other students. Similarly, Peterman and Kennedy (2003) found that entrepreneurship education enhances secondary students' perceived desirability and feasibility concerning business venture start-up. Souitaris et al. (2007) also found that entrepreneurship education fosters the development of certain entrepreneurial traits, especially inspiration towards entrepreneurship, a construct encompassing an emotional component.

Given the literature evidence on significant differences in entrepreneurial endowment dimensions for the variables of gender, culture and entrepreneurship education, the present study includes an analysis of differences in the entrepreneurial endowment for these three variables.

\section{Methodology}

This paper examines whether young people in South Africa possess an entrepreneurial endowment and to what extent. It follows a cross-sectional methodology, as it aims at determining the entrepreneurial-endowment levels of students in their current situation. It then examines significant differences in the entrepreneurial endowment according to gender, language and entrepreneurship education. The cultural dimension was measured using native language as a proxy, in line with other scholars (Laesser et al., 2014; Reuter, 2011).

\section{Sample}

Students at South African secondary schools, enrolled in Grades 10, 11 and 12, represented the target population of this paper. Respondents were aged 16 to 18 years old. The present investigation surveyed learners in 18 secondary schools, located in the South African provinces of Gauteng and Limpopo, from whom 827 valid responses were collected. For the purposes of selecting schools to include in the investigation, convenience sampling was followed, as the researchers contacted the secondary schools to which they had direct or indirect access. Conversely, random sampling was used to survey the students in each secondary school, as each student had an equal and known chance of being selected to take part in the study. Fifty-nine per cent of respondents were females. In terms of language, $49 \%$ of respondents spoke an African language, $20 \%$ spoke Afrikaans, 17\% spoke English and 14\% spoke another language as their native language. Finally, 49\% of respondents were enrolled in an after-school entrepreneurship education programme. 


\section{Measurement approaches}

From the perspective of the present study, which explores the existence of the entrepreneurial endowment dimensions among secondary students, it is worth examining the approaches followed by previous studies using similar sample populations in measuring different dimensions of the entrepreneurial profile of young people. The aim of this discussion is to identify measurement instruments for the entrepreneurial endowment dimensions investigated in this paper that are suitable for a secondary-student sample population.

Gürol and Atsan (2006) conducted an investigation of the entrepreneurial profile of university students in Turkey. They measured six traits, namely need for achievement, locus of control, risk taking propensity, tolerance of ambiguity, innovativeness and selfconfidence by using scales developed and validated in adult contexts. De Pillis and Reardon (2007) followed the same approach in measuring the entrepreneurial personality traits of self-efficacy, need for achievement and tolerance of ambiguity among a sample of undergraduate and MBA students in the USA and Ireland. Other studies come closer to the present study in their use of secondary students as the sample population. Dinis et al. (2013) and Marques et al. (2012) investigated the personality dimension of locus of control, risk-taking propensity, self-confidence, need for achievement, tolerance of ambiguity and innovativeness among secondary students. They both used Koh's (1996) scale, which was developed with MBA students in Hong Kong.

Few measures of entrepreneurial profile dimensions are available for young people, and there is no evidence of such measures for the entrepreneurial endowment investigated in this paper. Harris and Gibson (2008), for instance, were able to measure undergraduate university students' entrepreneurial attitudes using Robinson et al.'s (1991) Entrepreneurial Attitudes Orientation scale, which was developed with university students and validated with entrepreneurs and non-entrepreneurs. Schröder and SchmittRodermund (2006), who investigated the entrepreneurial personality traits of need for achievement, social dominance, risk-taking propensity and locus of control among secondary students in Germany, could make use of German age-appropriate versions of scales originally developed for adult respondents.

Scholars not in possession of ad-hoc scales for the variables they are measuring among young people have usually made adaptations to scales originated for adult populations. This is the case, for instance, of Thomas and Mueller (2000), who surveyed university students in nine different countries: the United States of America, Canada, 
Ireland, Germany, Belgium, Croatia, Slovenia, China and Singapore. In measuring respondents' innovativeness, locus of control, risk-taking propensity and energy level, they adopted scales from adult sample populations and modified them to make them more appropriate for the youth sample population of their study.

In sum, from the point of view of the secondary-school sample population of this study, previous studies have followed two approaches. Authors such as Gürol and Atsan (2006), Thomas and Mueller (2000) and Mueller and Thomas (2001) have focused on older youth populations (university students), while authors such as Dinis et al. (2013), Marques et al. (2012) and Schröder and Schmitt-Rodermund (2006) surveyed secondary students. However, they all adopted measurement instruments constructed and used for adult populations, with the exception of the study by Robinson et al. (1991), where a scale was developed with university students together with adults. This paper followed the same measurement approach and built on previous studies to develop a measurement instrument for the entrepreneurial endowment by identifying suitable measurement instruments originally developed for older populations, performing some adaptations where appropriate. The following section describes the measurement instrument employed in this study and identifies the measurement scales adopted from previous studies.

\section{Instrument}

The data collection instrument was a questionnaire measuring the six constructs constituting the entrepreneurial endowment and demographic data. The questionnaire was divided into four sections: three sections measuring the entrepreneurial endowment, whereby questionnaire items were grouped together based on the rating scale used, and a section collecting respondents' demographic data.

One section contained statements measuring the entrepreneurial endowment dimensions of locus of control, tolerance of ambiguity, role models and community support. These constructs were measured by statements on a five-point Likert rating scale, where 1 = "strongly disagree" and $5=$ "strongly agree". Locus of control was measured by eleven statements, adopted from Louden (1978) and converted from questions to statements. Tolerance of ambiguity was measured by twelve statements, as formulated by Herman et al. (2010). Twelve statements measured role models, adopted from Nauta and Kokaly (2001). Community support was measured by ten statements, sourced from Liao and Welsch (2005). Some of these statements were modified to make them more comprehensible to and suited for secondary students. Since the statements measuring 
these constructs were rated on the same Likert rating scales, it was possible to mix the order in which they appeared in the questionnaire. This procedure allowed the researchers to minimise self-report bias, which may be greater if respondents understand what they are being measured on and subsequently decide how they would like to rate themselves on a specific construct (Donaldson and Grant-Vallone, 2002). Another section covered statements measuring need for achievement. It was composed of five Likert items, taken from Steers and Braunstein's (1976) Measure of Manifest Needs. Respondents were asked to rate the statements on a five-point Likert rating scale that measured frequency, where 1 = "never" and 5 = "always". The third section measured family support and was made up of seven Likert items, sourced from Carr and Sequeira's (2007) Measure of Perceived Family Support. The five-point Likert rating scale for this construct measured quality and ranged from $1=$ "extremely negative" to $5=$ "extremely positive". Finally, the questionnaire included a section with categorical statements that measured demographic data on nominal scales. More specifically, this section measured respondents' gender, language and enrolment in an entrepreneurship education programme.

The data collection instrument was pre-tested to verify that all the statements, including those that were modified to suit the secondary-school sample, were clear and unambiguous. The questionnaire pre-test involved thirteen Grade-12 students, who were given a chance to provide feedback after completing the questionnaire. The students found all the questionnaire's statements to be clear and the questionnaire easy to complete. Therefore, the questionnaire was subsequently finalised with no alterations.

\section{Statistical procedure}

A systematic iterative approach was followed in the investigation of the entrepreneurial endowment among the population of this study. A first assessment of internal consistency reliability of the entrepreneurial endowment dimensions involved an inspection of the corrected item-total correlation of each item within the set of items for each construct. Values lower than 0.3 are considered indicative that a particular item does not correlate very well with the scale (Field, 2013). The pool of items measuring the entrepreneurial endowment dimensions was subsequently subjected to an exploratory factor analysis. This statistical test was performed to reveal the underlying structure of the data and, thus, the existence of entrepreneurial endowment dimensions. Items with high cross-loadings were identified and evaluated. Any items with low or double loadings were removed from further analyses. In order to determine whether the dimensions of locus of control, tolerance of 
ambiguity, role models and community support represented distinct constructs, an exploratory factor analysis was conducted using maximum likelihood estimation with direct quartimin rotation.

Individual exploratory factor analyses were conducted for the dimensions of need for achievement and family support, even though the size and direction of their Likert rating scales were equal to the other constructs. As for need for achievement, this procedure was followed because its Likert rating scale middle value "sometimes" does not equally correspond to a neutral rating as the middle value "neither agree nor disagree" used with other constructs. With regard to family support, respondents were asked to rate other people's perceptions about their (respondents') starting a business, as opposed to self-reporting statements used to measure the other constructs. For this reason, it was deemed that a separate exploratory factor analysis for the family support construct represented an approach leading to less error. Consequently, an exploratory factor analysis using principal component extraction and varimax rotation was run on need for achievement and family support individually to verify their uni-dimensionality.

We subsequently proceeded to determine the internal consistency reliability of the constructs that resulted from the above procedures. Finally, in order to analyse significant differences in the entrepreneurial endowment dimensions according to the gender, language and level of entrepreneurship education of respondents, t-tests and ANOVA were performed.

\section{Results}

The factor analysis for locus of control, tolerance of ambiguity, role models and community support suggested the existence of four factors, based on the eigenvalue-greater-than-one criterion and an overall variance explained of $30.3 \%$. As shown in Table 1, four factors emerged: locus of control, role models (guidance), role models (inspirational figure) and community support. This factor analysis could not identify tolerance of ambiguity as a factor. Furthermore, respondents distinguished between having i) role models that give them guidance and support in their career and life decisions, and ii) role models that inspire them in their career pursuits. 
Table 1: Exploratory factor analysis results for locus of control, tolerance of ambiguity, role models and community support

\begin{tabular}{ccccc}
\hline Factor & $\begin{array}{c}\text { Role } \\
\text { models } \\
\text { (guidance) }\end{array}$ & $\begin{array}{c}\text { Communi- } \\
\text { ty support }\end{array}$ & $\begin{array}{c}\text { Role } \\
\text { models }\end{array}$ & Locus of \\
(inspiratio & control \\
nal figure)
\end{tabular}

\begin{tabular}{|c|c|c|c|c|}
\hline \multirow{2}{*}{$\begin{array}{l}\text { Statement } \\
\text { There is someone who supports me in the } \\
\text { career choices I make. }\end{array}$} & \multicolumn{4}{|c|}{ Factor loadings } \\
\hline & $0.763^{a}$ & -0.069 & 0.080 & -0.056 \\
\hline $\begin{array}{l}\text { There is someone I can count on to be there if } \\
\text { I need support when I make career choices. }\end{array}$ & 0.668 & -0.012 & 0.007 & -0.046 \\
\hline $\begin{array}{l}\text { There is someone who helps me weigh the } \\
\text { pros and cons of the career choices I make. }\end{array}$ & 0.624 & 0.028 & -0.026 & -0.080 \\
\hline $\begin{array}{l}\text { There is no one who supports me when I } \\
\text { make career decisions. }\end{array}$ & 0.577 & -0.124 & 0.012 & 0.199 \\
\hline $\begin{array}{l}\text { There is someone who tells or shows general } \\
\text { strategies for a successful life. }\end{array}$ & 0.472 & 0.225 & 0.079 & -0.094 \\
\hline $\begin{array}{l}\text { I feel that most of the time my parents listen to } \\
\text { what I have to say. }\end{array}$ & 0.392 & 0.045 & -0.036 & 0.082 \\
\hline $\begin{array}{l}\text { Banks and other investors go out their way to } \\
\text { help new businesses get started. }\end{array}$ & -0.008 & 0.621 & 0.030 & -0.103 \\
\hline $\begin{array}{l}\text { State and local governments provide good } \\
\text { support for those starting new businesses. }\end{array}$ & -0.032 & 0.579 & 0.066 & -0.216 \\
\hline $\begin{array}{l}\text { I feel that when good things happen they } \\
\text { happen because of hard work. }\end{array}$ & 0.053 & 0.513 & 0.044 & 0.201 \\
\hline $\begin{array}{l}\text { Young people are encouraged to be } \\
\text { independent and start their own businesses. }\end{array}$ & 0.042 & 0.510 & 0.007 & 0.050 \\
\hline $\begin{array}{l}\text { I am the kind of person who believes that } \\
\text { planning ahead makes things turn out better. }\end{array}$ & 0.012 & 0.450 & -0.001 & 0.194 \\
\hline $\begin{array}{l}\text { The local media does a good job covering } \\
\text { local business people. }\end{array}$ & -0.012 & 0.433 & 0.047 & -0.173 \\
\hline $\begin{array}{l}\text { Other community groups provide good support } \\
\text { for those starting new businesses. }\end{array}$ & 0.101 & 0.347 & 0.069 & -0.159 \\
\hline $\begin{array}{l}\text { A good teacher is one who makes you wonder } \\
\text { about your way of looking at things. }\end{array}$ & 0.011 & 0.337 & -0.018 & 0.055 \\
\hline $\begin{array}{l}\text { There is someone I am trying to be like in my } \\
\text { career pursuits. }\end{array}$ & -0.001 & -0.019 & 0.744 & -0.084 \\
\hline $\begin{array}{l}\text { There is no one I am trying to be like in my } \\
\text { career pursuits. }\end{array}$ & -0.117 & -0.048 & 0.715 & 0.077 \\
\hline $\begin{array}{l}\text { In the career path I am pursuing, there is } \\
\text { someone I admire. }\end{array}$ & 0.065 & 0.080 & 0.453 & -0.050 \\
\hline $\begin{array}{l}\text { There is no one particularly inspirational to me } \\
\text { in the career path I am pursuing. }\end{array}$ & 0.166 & 0.029 & 0.320 & 0.186 \\
\hline
\end{tabular}




\begin{tabular}{|c|c|c|c|c|}
\hline Factor & $\begin{array}{c}\text { Role } \\
\text { models } \\
\text { (guidance) }\end{array}$ & $\begin{array}{l}\text { Communi- } \\
\text { ty support }\end{array}$ & $\begin{array}{c}\text { Role } \\
\text { models } \\
\text { (inspiratio } \\
\text { nal figure) }\end{array}$ & $\begin{array}{l}\text { Locus of } \\
\text { control }\end{array}$ \\
\hline $\begin{array}{l}\text { I feel that most of the time it doesn't pay to try } \\
\text { hard because things never turn out right } \\
\text { anyway. }\end{array}$ & 0.092 & 0.116 & 0.036 & 0.560 \\
\hline $\begin{array}{l}\text { I usually feel that it's almost useless to try in } \\
\text { school because most students are just plain } \\
\text { smarter than I am. }\end{array}$ & -0.014 & 0.220 & 0.033 & 0.489 \\
\hline $\begin{array}{l}\text { I feel that one of the best ways to handle most } \\
\text { problems is just not to think about them. }\end{array}$ & -0.050 & -0.143 & -0.011 & 0.399 \\
\hline $\begin{array}{l}\text { I often feel that whether or not I do my } \\
\text { homework this has little to do with the kind of } \\
\text { grades I get. }\end{array}$ & -0.051 & -0.125 & -0.016 & 0.349 \\
\hline $\begin{array}{l}\text { I feel that it's really impossible to change my } \\
\text { parents' mind about anything. }\end{array}$ & 0.118 & -0.129 & 0.069 & 0.316 \\
\hline $\begin{array}{l}\text { I am often blamed for things that just aren't my } \\
\text { fault. }\end{array}$ & 0.072 & 0.089 & -0.022 & 0.286 \\
\hline No. of items in factor & 6 & 8 & 4 & 6 \\
\hline Eigenvalue & 4.12 & 2.50 & 1.68 & 1.57 \\
\hline$\%$ variance explained by factor & $14.41 \%$ & $7.47 \%$ & $4.34 \%$ & $4.08 \%$ \\
\hline$\%$ cumulative variance explained & $14.41 \%$ & $21.88 \%$ & $26.22 \%$ & $30.30 \%$ \\
\hline Cronbach alpha reliability & 0.76 & 0.71 & 0.66 & 0.54 \\
\hline
\end{tabular}

a rotated factor loadings.

A statistical explanation of why the data did not reveal the existence of tolerance of ambiguity as a construct lies in the results of the systematic iterative statistical procedure followed. Items of a given scale were removed if they displayed low corrected item-total correlation scores or if they had low or double factor loadings in exploratory factor analysis. This procedure led to only one item-"a good teacher is one who makes you wonder about your way of looking at things"-measuring tolerance of ambiguity remaining in the factor analysis. As shown in Table 1, this item loaded on the community support construct. One reason for this result could be that the respondents, which were secondary students, did not understand what each statement in Herman et al.'s (2010) scale was intended to measure, as all the items that were removed from further analyses had low factor loadings. 
Table 2: Exploratory factor analysis results for need for achievement

\begin{tabular}{lc}
\hline Factor & $\begin{array}{c}\text { Need for } \\
\text { achievement }\end{array}$ \\
\hline Statement & Factor loadings \\
\hline I try very hard to improve on my past performance. & 0.613 \\
I do my best work when my assignments are fairly & 0.608 \\
difficult. & \\
I try to perform better than my peers. & 0.537 \\
\hline No. of items in factor & 3 \\
Eigenvalue & 1.686 \\
\% variance explained & $56.2 \%$ \\
Cronbach alpha reliability & 0.60 \\
\hline
\end{tabular}

Regarding need for achievement, the Kaiser-Meyer-Olkin Measure of Sampling Adequacy equal to 0.641 and Bartlett's Test of Sphericity being significant $(p=0.000)$ both indicated that a factor analysis was appropriate. As shown in Table 2, the factor analysis confirmed the existence of a single construct, based on the eigenvalue-greater-than-one criterion, explaining $56.2 \%$ of the variance. The Cronbach's alpha value for need for achievement was equal to 0.60 , after eliminating two items to improve internal consistency results.

Table 3: Exploratory factor analysis results for family support

\begin{tabular}{|c|c|c|}
\hline Factor & Support (others) & Support (family) \\
\hline Statement & \multicolumn{2}{|c|}{ Factor loadings } \\
\hline $\begin{array}{l}\text { My co-students feel__ about my starting a } \\
\text { business. }\end{array}$ & 0.638 & \\
\hline $\begin{array}{l}\text { My close friends feel___ about my starting a } \\
\text { business. }\end{array}$ & 0.616 & \\
\hline $\begin{array}{l}\text { My neighbour feels ___ about my starting a } \\
\text { business. }\end{array}$ & 0.506 & \\
\hline $\begin{array}{l}\text { In general my acquaintances feel ___ _ about my } \\
\text { starting a business. }\end{array}$ & 0.421 & \\
\hline $\begin{array}{l}\text { My parent(s) feel ___ about my starting a } \\
\text { business. }\end{array}$ & & -0.769 \\
\hline $\begin{array}{l}\text { My brother/sister feels ___ about my starting a } \\
\text { business. }\end{array}$ & & -0.636 \\
\hline $\begin{array}{l}\text { In general my relatives feel ____ about my starting } \\
\text { a business. }\end{array}$ & & -0.417 \\
\hline No. of items in factor & 4 & 3 \\
\hline Eigenvalue & 2.930 & 1.018 \\
\hline
\end{tabular}




\begin{tabular}{lcc}
\hline Factor & Support (others) & Support (family) \\
\hline$\%$ variance explained by factor & $41.9 \%$ & $14.5 \%$ \\
$\%$ cumulative variance explained & $41.9 \%$ & $56.4 \%$ \\
Cronbach alpha reliability & 0.66 & 0.69 \\
\hline
\end{tabular}

As for family support, the Kaiser-Meyer-Olkin Measure of Sampling Adequacy of 0.806 and Bartlett's Test of Sphericity being significant $(p=0.000)$ both indicated that a factor analysis could be performed. The factor analysis, whose results are reported in Table 3, revealed the existence of two constructs, based on the eigenvalue-greater-than-one criterion, after rotating the factor loadings using the Oblimin with Kaiser Method. Together, these two constructs explained $56.4 \%$ of the variance. The original family support construct turned out to represent two sub-constructs, namely, support from members of one's close family and support from other people, such as friends, neighbours and acquaintances. The Cronbach's alpha was 0.69 for the former sub-construct and 0.66 for the latter.

Based on the results of the factor analyses and internal consistency tests performed, it was necessary to formulate new operational definitions. The final set of entrepreneurial endowment dimensions comprised seven constructs. Their operational definitions, descriptive statistics and correlations, are presented in Table 4 below. The significant but low correlations observed confirm that the entrepreneurial endowment dimensions are independent and represent separate constructs. The only moderate correlation was found between support (family) and support (others); however, as these two factors are sub-constructs of the original family support dimension, this result is not surprising. 
Table 4: Factors' operational definitions, descriptive statistics and correlations

\begin{tabular}{|c|c|c|c|c|c|c|c|c|c|c|}
\hline Factor & Operational definition & Mean & S.D. & 1 & 2 & 3 & 4 & 5 & 6 & 7 \\
\hline $\begin{array}{l}\text { (1) Need for } \\
\text { achievement }\end{array}$ & $\begin{array}{l}\text { People's desire to seek challenging tasks, } \\
\text { accept responsibility for them and } \\
\text { demand feedback on their execution }\end{array}$ & 4.27 & 0.64 & 1.00 & & & & & & \\
\hline (2) Locus of control & $\begin{array}{l}\text { People's perception that they are the } \\
\text { determinants of the occurrences in their } \\
\text { lives }\end{array}$ & 3.37 & 0.68 & $0.12^{* * *}$ & 1.00 & & & & & \\
\hline $\begin{array}{l}\text { (3) Role models } \\
\text { (guidance) }\end{array}$ & $\begin{array}{l}\text { People's perception that they have } \\
\text { someone that supports them in their } \\
\text { career and life decisions }\end{array}$ & 3.92 & 0.73 & $0.23^{* \star *}$ & $0.20^{* \star *}$ & 1.00 & & & & \\
\hline $\begin{array}{l}\text { (4) Role models } \\
\text { (inspirational figure) }\end{array}$ & $\begin{array}{l}\text { The presence of someone that inspires } \\
\text { people in their career pursuits }\end{array}$ & 3.36 & 0.89 & $0.22^{* \star *}$ & $0.08^{* *}$ & $0.30^{* * *}$ & 1.00 & & & \\
\hline (5) Support (family) & $\begin{array}{l}\text { The perceived support received from } \\
\text { one's close family in starting a business }\end{array}$ & 3.95 & 0.70 & $0.24^{\star \star \star}$ & 0.05 & $0.38^{\star \star \star}$ & $0.24^{* \star *}$ & 1.00 & & \\
\hline (6) Support (others) & $\begin{array}{l}\text { The perceived support received from } \\
\text { people other than one's close family in } \\
\text { starting a business }\end{array}$ & 3.53 & 0.62 & $0.14^{\star \star \star}$ & $0.09^{* *}$ & $0.22^{\star \star \star}$ & $0.10^{\star \star \star}$ & $0.51^{* \star \star}$ & 1.00 & \\
\hline (7) Community support & $\begin{array}{l}\text { The support that people perceive the } \\
\text { community at large gives to } \\
\text { entrepreneurs }\end{array}$ & 3.84 & 0.56 & $0.40^{\star \star \star}$ & $-0.06^{*}$ & $0.27^{\star \star *}$ & $0.23^{* \star *}$ & $0.36^{\star \star \star}$ & $0.25^{\star * *}$ & 1.00 \\
\hline
\end{tabular}

${ }^{* * *} \mathrm{p}<0.01 ;{ }^{* *} \mathrm{p}<0.05 ;{ }^{*} \mathrm{p}<0.10$ 
In order to determine whether there was a statistically significant difference between the mean scores of the entrepreneurial endowment dimensions across nominal variables with two categories, namely gender and entrepreneurship education, independent t-tests were performed. When the Levene test for equality of variances was statistically significant $(p<0.05)$, the corresponding $t$ and $p$ values for equal variances not assumed were used. The t-test (Table 5 ) revealed that male and female respondents exhibited statistically significant differences $(p<0.05)$ for three entrepreneurial endowment dimensions, namely need for achievement, role models (guidance) and community support. In terms of entrepreneurship education, the secondary students participating in an entrepreneurship education programme differed significantly $(p<0.05)$ from the control group in five dimensions: need for achievement, locus of control, role models (inspirational figure), support (family) and community support.

A closer look at the mean scores for the entrepreneurial endowment dimension reported in Table 5 indicates that females scored statistically significantly higher on need for achievement, role models (guidance) and community support. Respondents enrolled in an entrepreneurship education programme scored statistically significantly higher on need for achievement, role models (inspirational figure), support (family) and community support, but recorded a statistically significant lower mean for locus of control.

To compare respondents' behaviour on the language variable, which had more than two categories, it was necessary to perform ANOVA, whose results are presented in Table 6 . Respondents of different language groups displayed statistically significant $(p<0.05)$ differences for the entrepreneurial endowment dimensions of need for achievement, locus of control, role models (inspirational figure), support (family) and community support. 
Table 5: T-test group statistics

\begin{tabular}{|c|c|c|c|c|c|c|c|c|c|c|}
\hline \multirow[b]{2}{*}{ Variable } & \multicolumn{5}{|c|}{ Gender } & \multicolumn{5}{|c|}{ Entrepreneurship education (EE) } \\
\hline & t-value & Groups & $\mathbf{N}$ & Mean & S.D. & t-value & Groups & $\mathbf{N}$ & Mean & S.D. \\
\hline \multirow{2}{*}{$\begin{array}{l}\text { Need for } \\
\text { achievement }\end{array}$} & \multirow{2}{*}{$-7.063^{* * *}$} & Male & 335 & 4.08 & 0.67 & \multirow{2}{*}{$-14.192^{* * *}$} & Control & 423 & 3.99 & 0.67 \\
\hline & & Female & 491 & 4.40 & 0.59 & & $\mathrm{EE}$ & 404 & 4.56 & 0.47 \\
\hline \multirow{2}{*}{ Locus of control } & \multirow{2}{*}{-1.005} & & 335 & 3.34 & & \multirow{2}{*}{$3.723^{* \star *}$} & Control & 423 & 3.46 & 0.67 \\
\hline & & Female & 491 & 3.39 & 0.66 & & EE & 404 & 3.28 & 0.67 \\
\hline \multirow{2}{*}{$\begin{array}{l}\text { Role models } \\
\text { (guidance) }\end{array}$} & \multirow{2}{*}{$-3.681^{\star \star \star}$} & Male & 335 & 3.80 & 0.77 & \multirow{2}{*}{-1.382} & Control & 423 & 3.88 & 0.75 \\
\hline & & Female & 491 & 3.99 & 0.69 & & $\mathrm{EE}$ & 404 & 3.95 & 0.71 \\
\hline \multirow{2}{*}{$\begin{array}{l}\text { Role models } \\
\text { (inspirational } \\
\text { figure) }\end{array}$} & \multirow[b]{2}{*}{0.544} & Male & 335 & 3.38 & 0.91 & \multirow{2}{*}{$-4.872^{\star \star \star}$} & Control & 423 & 3.21 & 0.92 \\
\hline & & Female & 491 & 3.34 & 0.87 & & EE & 404 & 3.51 & 0.83 \\
\hline \multirow{2}{*}{ Support (family) } & \multirow{2}{*}{-0.895} & Male & 335 & 3.93 & 0.69 & \multirow{2}{*}{$-7.586^{\star \star \star}$} & Control & 423 & 3.77 & 0.69 \\
\hline & & Female & 491 & 3.97 & 0.71 & & EE & 402 & 4.13 & 0.67 \\
\hline \multirow{2}{*}{ Support (others) } & \multirow{2}{*}{0.227} & Male & 335 & 3.54 & 0.59 & \multirow{2}{*}{$-1.784^{*}$} & Control & 423 & 3.50 & 0.56 \\
\hline & & Female & 491 & 3.53 & 0.64 & & $\mathrm{EE}$ & 404 & 3.57 & 0.68 \\
\hline \multirow{2}{*}{$\begin{array}{l}\text { Community } \\
\text { support }\end{array}$} & \multirow{2}{*}{$-8.264^{\star \star \star}$} & Male & 335 & 3.65 & 0.56 & \multirow{2}{*}{$-18.508^{\star \star \star}$} & Control & 423 & 3.55 & 0.47 \\
\hline & & Female & 491 & 3.97 & 0.52 & & EE & 404 & 4.15 & 0.47 \\
\hline
\end{tabular}

${ }^{* * *} p<0.01 ;{ }^{* *} p<0.05 ;{ }^{*} p<0.10$ 
Table 6: Analysis of variance for entrepreneurial endowment dimensions and language

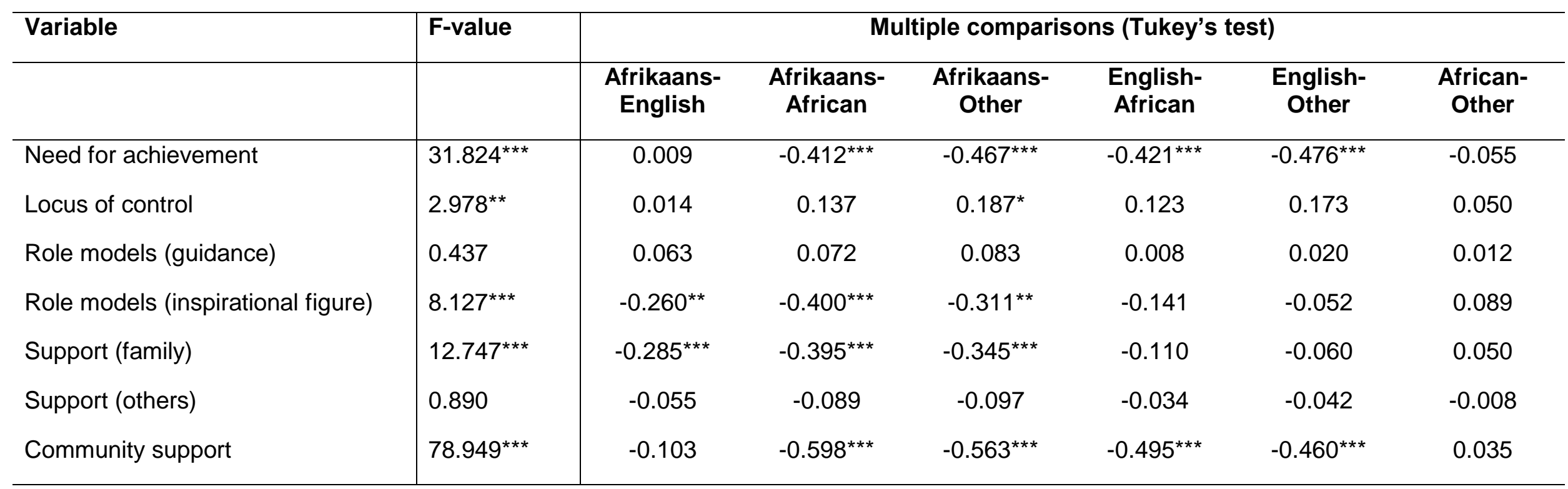

${ }^{\star * *} p<0.01 ;{ }^{* *} p<0.05 ;{ }^{*} p<0.10$ 
To get deeper insights into these results, Tukey's post hoc test was performed, which allowed for the comparison of pairwise differences between language groups. In terms of need for achievement, respondents of African and Other language scored significantly higher than respondents of Afrikaans and English language. Afrikaans respondents had higher levels of locus of control than respondents of Other language, but this difference was not highly significant. For role models (inspirational figure), respondents of English, African or Other language scored higher than Afrikaans-speaking respondents. This same comparison applied to support (family). Finally, respondents of African and Other language exhibited significantly higher levels of community support than respondents of Afrikaans and English language.

\section{Discussion}

The data-analysis results revealed that the entrepreneurial endowment exhibited by learners at South African secondary schools is composed of the following dimensions: i) need for achievement; ii) locus of control; iii) community support; iv) role models (guidance); v) role models (inspirational figure); vi) support (family); and vii) support (others). The latter four dimensions emerged for the first time in this paper and can be considered unique to the context of investigation. Figure 1 depicts the seven entrepreneurial endowment dimensions that were validated in this paper.

The results revealed that students at South African secondary schools exhibit high levels of the entrepreneurial endowment dimension of need for achievement. There is evidence that need for achievement is a personality trait consistently associated with entrepreneurship (Walter and Heinrichs, 2015). This means that secondary students in South Africa have the achievement motivation level needed to perform entrepreneurial tasks. Respondents also displayed moderate levels of the entrepreneurial endowment dimension of locus of control. Hence, students at South African secondary schools seem to have only a moderate perception that they are the determinants of the outcomes of their actions. Part of this behaviour could be attributed to the presence of external locus of control, which is associated with a more passive attitude (Rauch and Frese, 2007) and which is less congruent with performing entrepreneurial tasks. 


\section{Figure 1: Entrepreneurial endowment framework}

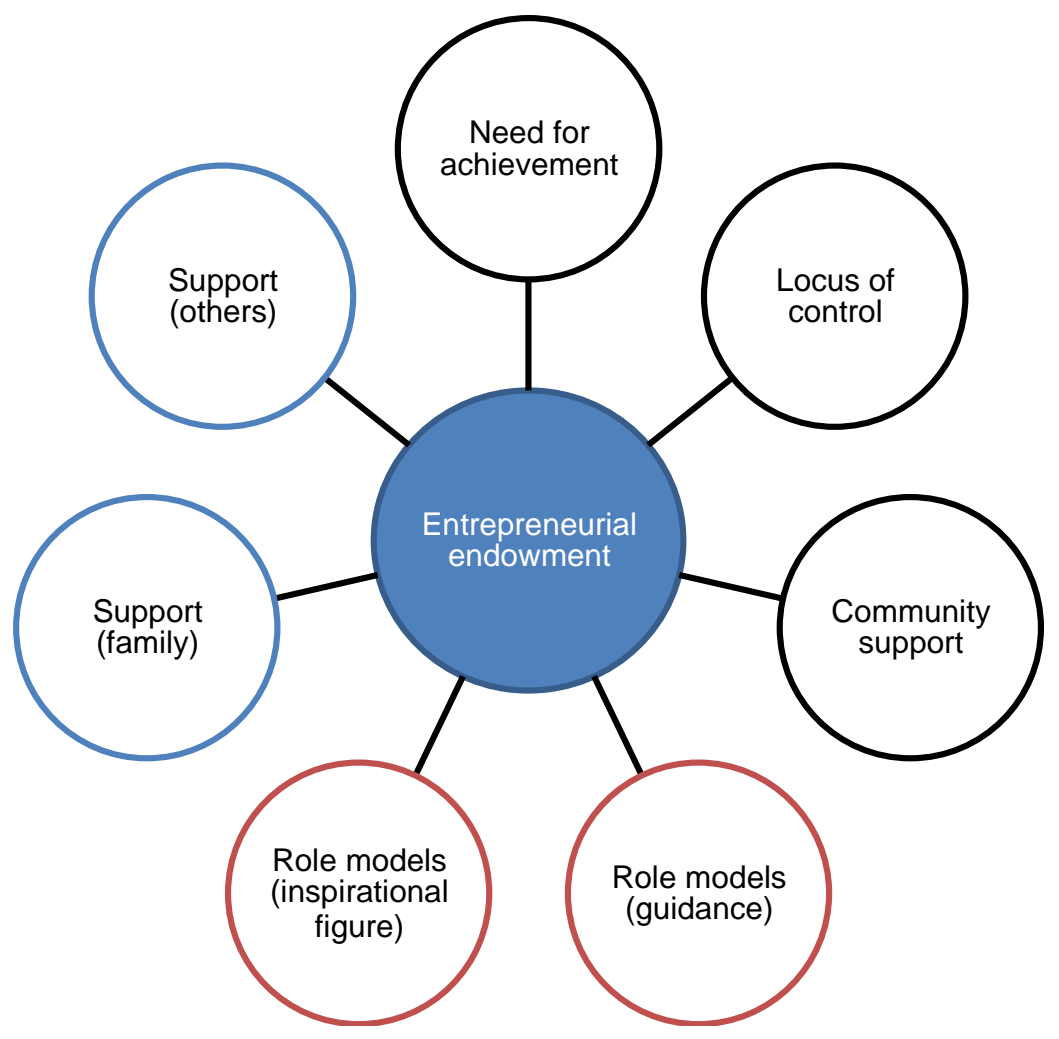

Source: Authors' own compilation

The entrepreneurial endowment dimension of role models was represented by two subconstructs: role models (guidance) and role models (inspirational figure). Respondents exhibited high levels of role models (guidance) and moderate levels of role models (inspirational figure). This means that students at South African secondary schools have someone to guide them in their entrepreneurial endeavours. Role models in terms of people who inspire students to be entrepreneurial are not as relevant. This latter finding is in line with claims that South Africa lacks good media coverage of entrepreneurial success cases (Herrington et al., 2015). The entrepreneurial endowment dimension of family support also behaved uniquely and was represented by two sub-constructs: support (family) and support (others). Respondents scored high on support (family) and moderate on support (others). It appears, therefore, that members of students' close family, such as parents, siblings and relatives, are supportive of their entrepreneurial intentions. On the contrary, people outside of their family circle, such as friends, peers, neighbours and acquaintances, are not as supportive. Finally, community support also emerged as an entrepreneurial endowment dimension displayed by students at South African secondary schools. Respondents scored high on this dimension, signifying that there is support for 
their entrepreneurial endeavours from the community at large. This finding is relevant for a context like South Africa characterised by a collectivistic culture (Triandis, 1989).

Tolerance of ambiguity was the only construct that respondents of the present investigation did not display as an entrepreneurial endowment dimension. This finding is in contrast with similar studies conducted in other settings (Dinis et al., 2013; Marques et al., 2012), where secondary students displayed tolerance of ambiguity as a trait. As explained in the results section, this finding is attributable chiefly to a measurement problem with Herman et al.'s (2010) scale in this study's context of investigation, rather than to the behaviour of secondary students in terms of this entrepreneurial endowment dimension.

The results of this study revealed gender differences for some entrepreneurial endowment dimensions. In contrast with Tessema Gerba (2012), female secondary students reported higher levels of need for achievement than males. Entrepreneurship education programmes that aim to increase participants' need for achievement should, therefore, pay special attention to male participants. Male secondary students also appear to have fewer role models that guide them in their entrepreneurial career pursuits. They also reported lower levels of support from their community in their entrepreneurial endeavours. In the light of the gender stereotypes faced by women in matters such as access to finance (Marlow and Patton, 2005), these findings could signify that female secondary students rely more than males on people who act as mentors and on social networks to overcome such barriers, especially in a collectivistic and community-oriented environment such as that characterising Africa (Khayesi et al., 2014).

As it appears from the findings of this study, secondary students participating in an entrepreneurship education programme have higher levels of need for achievement and more role models that inspire them in their career pursuits than those not undergoing entrepreneurship education. Therefore, there is potential in South Africa for fostering need for achievement and showcasing entrepreneurial success stories through carefully built entrepreneurship education programmes. Secondary students enrolled in an entrepreneurship education programme also reported greater support from their family and community in their entrepreneurial endeavours. Future research could investigate the direction of these relationships, i.e. whether entrepreneurship education encourages participants' family and community to support them in their business start-up activities, or if people with support from their family and community are more likely to enrol in an entrepreneurship education programme. 
In terms of culture, secondary students with an African and Other cultural background had significantly higher levels of need for achievement and community support than both students with Afrikaans and English cultural backgrounds. This finding could be in line with the observation that young people in Sub-Saharan Africa have higher levels of entrepreneurial intentions than young people in other parts of the world (Kew et al., 2013), which could be ascribed to higher levels of need for achievement and, once again, to the role played by their community and extended family in entrepreneurial activities (Khayesi et al., 2014). Secondary students of African and Other cultural background also reported having role models that inspire their entrepreneurial pursuits and having support from their family significantly more than Afrikaans students. These findings are in contrast with the observation that in the early 2000s black South Africans lacked entrepreneurial role models and displayed lower levels of entrepreneurial activity within this ethnic group (Herrington et al., 2010). The findings of this study could signal a shift in the support received from family and in the presence of role models within the black South African community, also owing to the emergence of successful entrepreneurs from this ethnic group.

\section{Conclusion}

The economic potential of young people has been compromised by the rising wave of youth unemployment in recent years. Entrepreneurship is seen as a possible solution to the youth unemployment dilemma, as starting one's own business is a viable employment option. Various initiatives to foster youth entrepreneurship have therefore been put in place, ranging from education and training to funding. In South Africa, a number of entrepreneurship-education-and-training and funding institutions have been set up to enable successful business start-up among the general population, as well as among the youth. However, as promising as these initiatives may seem, they often do not achieve the intended results, or only do so partially. Furthermore, the question that now arises is whether entrepreneurship-education-and-training and funding initiatives target the right young people. Since there is a wish that as many young people as possible start their own businesses, a legitimate question is whether young people in South Africa possess what it takes to be successful entrepreneurs. Numerous variables are required to enable successful entrepreneurship. Evidence exists that certain personality traits and contextual variables, termed "entrepreneurial endowment" in this paper, are associated with entrepreneurship. 
This paper investigated whether students at South African secondary schools possess an entrepreneurial endowment consisting of the personality traits of need for achievement, locus of control and tolerance of ambiguity, as well as the contextual variables of role models, family support and community support. It was found that secondary students in South Africa exhibit high levels of need for achievement and community support and moderate levels of locus of control. Tolerance of ambiguity did not emerge as an entrepreneurial endowment dimension. Furthermore, new entrepreneurial endowment dimensions emerged. Respondents exhibited high levels of role models relating to someone that offers guidance and support and a high level of support from close family members. They also displayed moderate levels of role models relating to someone who serves as an inspirational figure and of support from people outside the close family circle. These four constructs are not found in previous research and represent four dimensions uniquely displayed by young South Africans.

Finally, this paper uncovered significant differences in the entrepreneurial endowment of secondary students from perspective of gender, cultural background and entrepreneurship education, thus providing further insights into the dynamics of the entrepreneurial endowment of secondary students in South Africa.

From a theoretical perspective, this study postulates that young people in South Africa exhibit an entrepreneurial endowment composed of: need for achievement, locus of control, role models (guidance), role models (inspirational figure), support (family), support (others) and community support. The major contribution of this paper is the validation of a specific entrepreneurial endowment that young people in South Africa possess.

\section{Implications for practice}

From a practice perspective and under an entrepreneurial-endowment lens, these findings imply that young people in South Africa are rightfully the target of interventions aimed at fostering youth entrepreneurship, except for the fact that they do not display tolerance of ambiguity. However, given that only 13 per cent of young people in South Africa exhibit entrepreneurial intentions (Herrington et al., 2015), it can be postulated that other variables, such as lack of capital, skills, support and market opportunities (Kew et al., 2013), interact with the entrepreneurial endowment to influence entrepreneurship. It would seem, therefore, that more attention should be given to overcoming external obstacles to youth entrepreneurship of a bureaucratic and financial nature. 
It also appears from this study that female students and students from an African cultural background should be especially the target of youth entrepreneurship interventions, given their higher levels of need for achievement, role models, family support and community support. However, attention should be paid in directing young people towards more opportunity-oriented entrepreneurial activities, especially young black Africans, given the higher proportion of necessity entrepreneurship within this population (Herrington et al., 2010). This could be achieved through more carefully devised entrepreneurship education initiatives, as current efforts in South Africa have largely fallen short of creating the opportunity-oriented, high-growth business ventures that create and sustain jobs (Herrington and Kew, 2016).

\section{Limitations and future research}

Even though this study attempts to make a valuable contribution to research on the education and training of the youth and the unemployed, no study is without limitations. One such limitation is the use of a convenience sampling to identify the secondary schools included in the investigation. Therefore, the findings of this paper are not generalizable to the entire population of secondary students in South Africa.

The entrepreneurial endowment framework was kept parsimonious with a view towards compiling a concise measurement instrument suited for secondary students. The downside of this approach is that more entrepreneurial endowment dimensions could have been included in the study. Future research could investigate other personality traits and contextual variables that may expand this framework and add to the entrepreneurial endowment variables considered in this paper. In the light of the methodological issues encountered with the measurement of tolerance of ambiguity, a measurement scale specifically validated in a youth context could be used in future research to fill the gap left by this study. In the absence of such a scale, the development thereof would represent a significant contribution in the field of youth entrepreneurship.

This paper is limited to the investigation of secondary students' display of a certain entrepreneurial endowment. However, the motivation behind this approach is the understanding of whether young people in South Africa are rightfully the target of interventions aimed at fostering youth entrepreneurship, specifically from an entrepreneurial-endowment viewpoint. Since youth entrepreneurial intentions according to Kew et al. (2015) are low among South African youth, future research could address this research dilemma from the perspective of other variables potentially responsible for these 
entrepreneurial-intentions levels. Moreover, there is scope for extending the findings of this study by comparing the entrepreneurial endowment of young people and of adults, so as to discover if the set of personality traits and contextual variables becomes more entrenched over time.

\section{References}

Altinay, L., Madanoglu, M., Daniele, R. and Lashley, C. (2012), "The influence of family tradition and psychological traits on entrepreneurial intention", International Journal of Hospitality Management, Vol. 31 No. 2, pp. 489-499.

Bell, D.N.F. and Blanchflower, D.G. (2011), "Young people and the Great Recession", Oxford Review of Economic Policy, Vol. 27 No. 2, pp. 241-267.

Bosma, N., Hessels, J., Schutjens, V., Van Praag, M. and Verheul, I. (2012), "Entrepreneurship and role models", Journal of Economic Psychology, Vol. 33 No. 2, pp. 410-424.

Brandstätter, H. (2011), "Personality aspects of entrepreneurship: a look at five metaanalyses", Personality and Individual Differences, Vol. 51 No. 3, pp. 222-230.

Caliendo, M., Fossen, F. and Kritikos, A.S. (2014), "Personality characteristics and the decisions to become and stay self-employed", Small Business Economics, Vol. 42 No. 4, pp. 787-814.

Carr, J.C. and Sequeira, J.M. (2007), "Prior family business exposure as intergenerational influence and entrepreneurial intent: a theory of planned behavior approach", Journal of Business Research, Vol. 60 No. 10, pp. 1090-1098.

Chang, E.P.C., Memili, E., Chrisman, J.J., Kellermanns, F.W. and Chua, J.H. (2009), "Family social capital, venture preparedness, and start-up decisions: a study of Hispanic entrepreneurs in New England”, Family Business Review, Vol. 22 No. 3, pp. 279-292. 
Chlosta, S., Patzelt, H., Klein, S.B. and Dormann, C. (2010), "Parental role models and the decision to become self-employed: the moderating effect of personality", Small Business Economics, Vol. 38 No. 1, pp. 121-138.

De Pillis, E. and Reardon, K.K. (2007), "The influence of personality traits and persuasive messages on entrepreneurial intention: a cross-cultural comparison", Career Development International, Vol. 12 No. 4, pp. 382-396.

Dinis, A., Paço, A., Ferreira, J., Raposo, M. and Rodrigues, R.G. (2013), "Psychological characteristics and entrepreneurial intentions among secondary students", Education + Training, Vol. 55 No. 8/9, pp. 763-780.

Donaldson, S.I. and Grant-Vallone, E.J. (2002), "Understanding self-report bias in organizational behavior research", Journal of Business and Psychology, Vol. 17 No. 2, pp.245-260.

Espíritu-Olmos, R. and Sastre-Castillo, M.A. (2015), "Personality traits versus work values: comparing psychological theories on entrepreneurial intention", Journal of Business Research, Vol. 68 No. 7, pp. 1595-1598.

Farrington, S.M., Venter, D.J.L. and Louw, M.J. (2012), “Entrepreneurial intentions: demographic perspectives of South African business students", South African Journal of Business Management, Vol 43 No. 3, 41-49.

Farrington, S.M., Venter, D.J., Schrage, C.R. and Van der Meer, P.O. (2012), "Entrepreneurial attributes of undergraduate business students: a three country comparison revisited", South African Journal of Economic and Management Sciences, Vol. 15 No. 4, pp. 333-351.

Fatoki, O.O. and Chindoga, L. (2012), "Triggers and barriers to latent entrepreneurship in high schools in South Africa", Journal of Social Sciences, Vol. 31 No. 3, pp. 307318.

Field, A. (2013). Discovering statistics using IBM SPSS Statistics (4th ed.), Sage, London. 
Gartner, W.B. (1989), "Who is an entrepreneur?' is the wrong question", Entrepreneurship Theory and Practice, Vol. 13 No. 4, pp. 47-68.

Gürol, Y. and Atsan, N. (2006), "Entrepreneurial characteristics amongst university students: some insights for entrepreneurship education and training in Turkey", Education + Training, Vol. 48 No. 1, pp. 25-38.

Harris, M.L. and Gibson, S.G. (2008), "Examining the entrepreneurial attitudes of US business students", Education + Training, Vol. 50 No. 7, pp. 568-581.

Herman, J.L., Stevens, M.J., Bird, A., Mendenhall, M. and Oddou, G. (2010), "The tolerance for ambiguity scale: towards a more refined measure for international management research", International Journal of Intercultural Relations, Vol. 34 No. 1, pp. 58-65.

Herrington, M. and Kew, P. (2016), "South African Report 2015/2016: is South Africa heading for an economic meltdown?", Global Entrepreneurship Monitor, Cape Town, available at: http://www.gemconsortium.org/report/49537 (accessed 26 June 2016).

Herrington, M., Kew, J. and Kew, P. (2010), "Tracking entrepreneurship in South Africa: a GEM perspective", Global Entrepreneurship Monitor, Cape Town, available at: http://www.gemconsortium.org/report/47373 (accessed 15 June 2011).

Herrington, M., Kew, J. and Kew, P. (2015), "2014 GEM South Africa Report: South Africa: the crossroads - a goldmine or a time bomb?", Global Entrepreneurship Monitor, Cape Town, available at: http://www.gemconsortium.org/report/49154 (accessed 11 May 2015).

Hoffmann, A., Junge, M. and Malchow-Møller, N. (2014), "Running in the family: parental role models in entrepreneurship", Small Business Economics, Vol. 44 No. 1, pp. 79-104.

Hofstede, G. and McCrae, R.R. (2004), "Personality and culture revisited: linking traits and dimensions of culture", Cross-Cultural Research, Vol. 38 No. 1, pp. 52-88. 
Hsiao, C., Lee, Y.H. and Chen, H.H. (2016), "The effects of internal locus of control on entrepreneurship: the mediating mechanisms of social capital and human capital", The International Journal of Human Resource Management, Vol. 27 No. 11, pp. $1158-1172$.

ILO. (2015), "Global employment trends for youth 2015", International Labour Office, Geneva, available at: http://www.ilo.org/wcmsp5/groups/public/---dgreports/--dcomm/---publ/documents/publication/wcms_412015.pdf (accessed 5 January 2016).

Jayawarna, D., Rouse, J. and Kitching, J. (2013), "Entrepreneur motivations and life course", International Small Business Journal, Vol. 31 No. 1, pp. 34-56.

Karimi, S., Biemans, H.J.A., Lans, T., Chizari, M. and Mulder, M. (2014), "Effects of role models and gender on students' entrepreneurial intentions", European Journal of Training and Development, Vol. 38 No. 8, pp. 694-727.

Kew, J., Herrington, M., Litovsky, Y. and Gale, H. (2013), "Generation entrepreneur? The state of global youth entrepreneurship", Global Entrepreneurship Monitor and Youth Business International, Cape Town, available at: http://www.gemconsortium.org/ report/48590 (accessed 16 October 2014).

Kew, J., Namatovu, R., Aderinto, R. and Chigunta, F. (2015), "Africa's young entrepreneurs: unlocking the potential for a brighter future", Global Entrepreneurship Monitor, Cape Town, available at: http://www.gemconsortium.org/ report/49222 (accessed 4 November 2015).

Khayesi, J.N., George, G. and Antonakis, J. (2014), "Kinship in entrepreneur networks: performance effects of resource assembly in Africa. Entrepreneurship Theory and Practice, Vol. 38(6), pp.1323-1342.

Koh, H.C. (1996), "Testing hypotheses of entrepreneurial characteristics: a study of Hong Kong MBA students", Journal of Managerial Psychology, Vol. 11 No. 3, pp. 12-25. 
Korunka, C., Frank, H., Lueger, M. and Mugler, J. (2003), "The entrepreneurial personality in the context of resources, environment, and the startup process-a configurational approach", Entrepreneurship Theory and Practice, Vol. 28 No. 1, pp. 23-42.

Laesser, C., Beritelli, P. and Heer, S. (2014), "Different native languages as proxy for cultural differences in travel behaviour: insights from multilingual Switzerland", International Journal of Culture, Tourism and Hospitality Research, Vol. 8 No. 2, pp.140-152.

Leutner, F., Ahmetoglu, G., Akhtar, R. and Chamorro-Premuzic, T. (2014), "The relationship between the entrepreneurial personality and the Big Five personality traits", Personality and Individual Differences, Vol. 63, pp. 58-63.

Liao, J. and Welsch, H. (2005), "Roles of social capital in venture creation: key dimensions and research implications", Journal of Small Business Management, Vol. 43 No. 4, pp. 345-362.

Liñán, F. and Fayolle, A. (2015), "A systematic literature review on entrepreneurial intentions: citation, thematic analyses, and research agenda", International Entrepreneurship and Management Journal, pp. 1-27.

Llewellyn, D.J. and Wilson, K.M. (2003), "The controversial role of personality traits in entrepreneurial psychology", Education + Training, Vol. 45 No. 6, pp. 341-345.

Louden, D.M. (1978), “Internal versus external control in Asian and West Indian adolescents in Britain", Journal of Adolescence, Vol. 1 No. 3, pp. 283-296.

Marlow, S. and Patton, D. (2005), "All credit to men? Entrepreneurship, finance, and gender", Entrepreneurship Theory and Practice, Vol. 29 No. 6, pp. 717-735.

Marques, C.S., Ferreira, J.J., Gomes, D.N. and Rodrigues, R.G. (2012), "Entrepreneurship education: how psychological, demographic and behavioural factors predict the entrepreneurial intention”, Education + Training, Vol. 54 No. 8/9, pp. 657-672.

McClelland, D.C. (1961), The Achieving Society, Collier-Macmillan, New York. 
Meeus, W., Van de Schoot, R., Klimstra, T. and Branje, S. (2011), "Personality types in adolescence: change and stability and links with adjustment and relationships: a five-wave longitudinal study", Developmental Psychology, Vol. 47 No. 4, pp. 11811195.

Mueller, S.L. and Thomas, A.S. (2001), "Culture and entrepreneurial potential: a nine country study of locus of control and innovativeness", Journal of Business Venturing, Vol. 16 No. 1, pp.51-75.

Nauta, M.M. and Kokaly, M.L. (2001), “Assessing role model influences on students' academic and vocational decisions", Journal of Career Assessment, Vol. 9 No. 1, pp. 81-99.

Obschonka, M., Silbereisen, R.K. and Schmitt-Rodermund, E. (2012), "Explaining entrepreneurial behavior: dispositional personality traits, growth of personal entrepreneurial resources, and business idea generation", The Career Development Quarterly, Vol. 60 No. 2, pp. 178-190.

Peterman, N.E. and Kennedy, J. (2003), “Enterprise education: influencing students' perceptions of entrepreneurship", Entrepreneurship Theory and Practice, Vol. 28 No. 2, pp.129-144.Powell, G.N. and Eddleston, K.A. (2013), "Linking family-to-business enrichment and support to entrepreneurial success: do female and male entrepreneurs experience different outcomes?", Journal of Business Venturing, Vol. 28 No. 2, pp. 261-280.

Rauch, A. and Frese, M. (2007), "Let's put the person back into entrepreneurship research: a meta-analysis on the relationship between business owners' personality traits, business creation, and success", European Journal of Work and Organizational Psychology, Vol. 16 No. 4, pp. 353-385.

Reuter, C.H.J. (2011), "A survey of 'culture and finance"', Finance, Vol. 32 No. 1, pp.75152. 
Robinson, P.B., Stimpson, D.V., Huefner, J.C. and Hunt, H.K. (1991), "An attitude approach to the prediction of entrepreneurship", Entrepreneurship Theory and Practice, Vol. 15 No. 4, pp. 13-31.

Rotter, J.B. (1966), "Generalized expectancies for internal versus external control of reinforcement", Psychological Monographs, Vol. 80 No. 1, pp. 1-28.

Schröder, E. and Schmitt-Rodermund, E. (2006), "Crystallizing enterprising interests among adolescents through a career development program: the role of personality and family background", Journal of Vocational Behavior, Vol. 69 No. (3), pp.494509.

Singer, S., Amorós, J.E. and Moska, D. (2015), "Global Entrepreneurship Monitor 2014 Global Report”, Global Entrepreneurship Research Association, London, available at: http://www.gemconsortium.org/report/49079 (accessed 4 November 2015).

Souitaris, V., Zerbinati, S. and Al-Laham, A. (2007), "Do entrepreneurship programmes raise entrepreneurial intention of science and engineering students? The effect of learning, inspiration and resources", Journal of Business Venturing, Vol. 22 No. 4, pp.566-591.

Stam, W., Arzlanian, S. and Elfring, T. (2014), "Social capital of entrepreneurs and small firm performance: a meta-analysis of contextual and methodological moderators", Journal of Business Venturing, Vol. 29 No. 1, pp. 152-173.

Steers, R.M. and Braunstein, D.N. (1976), "A behaviorally-based measure of manifest needs in work settings", Journal of Vocational Behavior, Vol. 9 No. 2, pp. 251-266.

Stewart, W.H. and Roth, P.L. (2007), "A meta-analysis of achievement motivation differences between entrepreneurs and managers", Journal of Small Business Management, Vol. 45 No. 4, pp. 401-421. 
Tas, A., Citci, U.S. and Cesteneci, Y. (2012), "The role of immigration as a social network on shaping entrepreneurship tendency: a research on Balkan immigrant entrepreneurs in Turkey", Canadian Social Science, Vol. 8 No. 4, pp. 67-79.

Tessema Gerba, D. (2012), "Impact of entrepreneurship education on entrepreneurial intentions of business and engineering students in Ethiopia", African Journal of Economic and Management Studies, Vol. 3 No. 2, pp.258-277.

Thomas, A.S. and Mueller, S.L. (2000), "A case for comparative entrepreneurship: assessing the relevance of culture", Journal of International Business Studies, Vol. 31 No. 2, pp.287-301.

Triandis, H.C. (1989), "The self and social behavior in differing cultural contexts", Psychological Review, Vol. 96 No. 3, pp. 506-520.

Van Eeden, S., Louw, L. and Venter, D. (2005), "Entrepreneurial traits of undergraduate commerce students: a three-country comparison", Management Dynamics, Vol. 14 No. 3, pp. $26-43$.

Walter, S.G. and Heinrichs, S. (2015), "Who becomes an entrepreneur? A 30-years-review of individual-level research", Journal of Small Business and Enterprise Development, Vol. 22 No. 2, pp. 225-248.

Welter, F. (2011), "Contextualizing entrepreneurship—conceptual challenges and ways forward", Entrepreneurship Theory and Practice, Vol. 35 No. 1, pp. 165-184.

Wiklund, J., Davidsson, P., Audretsch, D.B. and Karlsson, C. (2011), "The future of entrepreneurship research", Entrepreneurship Theory and Practice, Vol. 35 No. 1, pp. 1-9.

Wilson, F., Kickul, J. and Marlino, D. (2007), "Gender, entrepreneurial self-efficacy, and entrepreneurial career intentions: implications for entrepreneurship Education", Entrepreneurship Theory and Practice, Vol. 31 No. 3, pp. 387-406. 
Zhao, H. and Seibert, S.E. (2006), "The Big Five personality dimensions and entrepreneurial status: a meta-analytical review", Journal of Applied Psychology, Vol. 91 No. 2, pp. 259-271.

Zhao, H., Seibert, S.E. and Lumpkin, G.T. (2010), "The relationship of personality to entrepreneurial intentions and performance: a meta-analytic review", Journal of Management, Vol. 36 No. 2, pp. 381-404. 